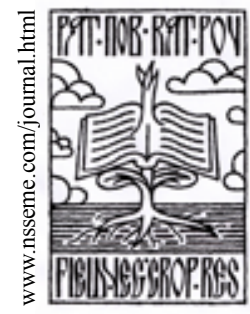

\title{
Productive and Quality Characteristics of Soybean in Agroecological Conditions of Sombor, Serbia
}

\author{
Vera Popović • Jegor Miladinović • Miloš Vidić • Mladen Tatić• \\ Vladimir Sikora • Jela Ikanović• Gordana Dozet
}

\author{
Received: 24 May 2013, accepted: 4 November 2013 \\ Published online: 15 November 2013 \\ (c) 2013 IFVC \\ doi: $10.5937 /$ ratpov $50-3921$
}

\begin{abstract}
Summary: The objective of this paper was to examine and present the results of soybean grain yield, protein and oil content during a two-year period (2009 to 2010) in agro-ecological conditions of Sombor, Serbia. Data were statistically analysed by analysis of variance, using the method of two factorial trials (variety, year). LSD was used to compare means for significant differences. Significantly higher yields were recorded in 2010 compared to 2009 . Average yield amounted to $4,196 \mathrm{~kg} \mathrm{ha}^{-1}$ for analysed soybean varieties, and ranged from $2,889 \mathrm{~kg} \mathrm{ha}^{-1}$ (2009) to 5,503 $\mathrm{kg} \mathrm{ha}^{-1}$ (2010). The year 2010 was favourable for protein synthesis. The highest protein content was achieved by Bečejka variety (38.38\%) and Proteinka variety (38.33\%) in 2010. Proteinka had statistically significantly higher average protein content compared to other tested varieties in the two-year average. The tested soybean varieties had average oil content of $20.93 \%$. The highest oil content was found in Sava variety (23.03\%) in 2009. Statistically significantly higher oil content was recorded in 2009 compared to 2010 , while variety and their interactions had statistically significant effect $(\mathrm{p}<0.05, \mathrm{p}<0.01)$ on yield and grain quality of soybean. Irrigation and appropriate cultural practices are the only measures that could mitigate limitation factors and increase yields.

Key words: grain yield, oil content, protein content, soybeans, variety
\end{abstract}

\section{Introduction}

From a little-known plant that was cultivated in the early twentieth century in a few countries, soybean (Glycine max. (L.) Merr.) became one of the most widely grown field crops in the world at the end of the 20th century (Miladinovic et al. 2008). In recent years, $90 \%$ of the world production has been concentrated in a few countries (USA, Brazil, Argentina, China, India, etc.). Areas and yields have had a growing tendency (and hence higher production) in recent years, in our country and abroad (Popović 2010). Regarding the favourable grain composition, soybean has been classified

V. Popović $c^{*}$ J. Miladinović • M. Vidić • M. Tatić• V. Sikora

Institute of Field and Vegetable Crops, Maksima Gorkog 30, 21000

Novi Sad, Serbia

e-mail:vera.popovic@nsseme.com

J. Ikanović

University of Belgrade, Faculty of Agriculture, Nemanjina 6, BelgradeZemun, Serbia

G. Dozet

University of Megatrend, Faculty of Biofarming, Maršala Tita 39, Bačka Topola, Serbia into the group of the most important plant protein and oil sources in the world. Because of high protein content with a high ratio of essential amino acids (Jayakumar et al. 2010), as well as high concentration of antioxidants (Cahoon 2003), and unsaturated fatty acids (McCord et al. 2004), soy has been recognized as functional food. Soybeans have multi-purpose: human and animal nutrition, proteins, oil and bio-diesel production.

The climate has a major effect on plant growth and development, and often represents a limiting production factor. Very important factors that influence the chemical composition of soybean grains are the prevailing environmental conditions during the growth phase, as well as specificities of a variety, in accordance with the results of Hurburgh (2000). Proper variety selection, besides the best cultivation technology use, has major influence on the yield increase and soybean grain quality in different environmental conditions (Miladinović et al. 2008, Vidić et al. 2010, Popović et al. 2013).

Acknowledgements:

Research presented in this paper was financed by the Ministry of Education, Science and Technological Development of the Republic of Serbia (Project TR 31022) and Republic of Montenegro (Project HERIC). 
Growing high yielding varieties resistant to diseases, pests and other adverse environmental conditions is very important for successful soybean production. Proper and timely agricultural practices can mitigate negative conditions that have a major impact on yield and soybean grain quality (Popović 2010). The aim of this study was to determine the productivity and soybean grain quality of varieties of Novi Sad in the region of Sombor, in agro-climatic divergent years.

\section{Materials and Methods}

Examination of varietal productivity during divergent examination years was on the PSS Sombor plot, experimental field Toplana, where experiments were performed during 2009 and 2010 on the chernozem meadow soil type. Four soybean varieties from the maturity group 0 (Galina, Valjevka, Bečejka and Proteinka) were used as material, as well as two varieties of the maturity group I (Balkan and Sava), which are at the same time the current assortment in our country. Field trials were designed as a two factorial trial with 3 replications using plots of $10 \mathrm{~m}^{2}$. Corn was the preceding crop.

Each year standard agricultural practices for soybean were applied. Before primary tillage, 400 $\mathrm{kgha}^{-1}$ of NPK fertilizer with 15:15:15 formulation was applied. Sowing was carried in the first half of April, with micro-experiments planter on 50 $\mathrm{cm}$ row spacing. Microbiological preparation NS Nitragin was applied during sowing. Crop density was 500,000 plants per hectare for the 0 maturity group and 450,000 plants per hectare for the maturity group I.

Harvest was performed in technological maturity with the micro-experiments combine. After harvest, grain yield $\left(\mathrm{kg} \mathrm{ha}^{-1}\right)$, protein and oil content (\%) were measured from each plot and converted to level of $14 \%$ of grain moisture. Chemical composition of soybean grain was determined by infrared spectroscopy technique with PERTEN DA 7000 apparatus (Spectrophotometer NIR / VIS) and non-destructive method. Experimental data were analysed by descriptive and analytical statistics, using the statistics software package Statistica 12 for Windows. The significance of differences among the mean values of different factors studied in the paper (year, genotype, interaction) was tested by adapted two-way ANOVA. All evaluations of significance were made on the basis of the LSD test at $0.05 \%$ and $0.01 \%$ significance levels. The stability of the analysed parameters was measured by the coefficient of variation $(\mathrm{Cv})$.

\section{Weather conditions}

The data from Sombor meteorological station were used for the analysis of weather conditions. The total amount of precipitation for the studied period was $476 \mathrm{~mm}$ and ranged from $258 \mathrm{~mm}$ (2009) to $694 \mathrm{~mm}$ (2010), Fig. 1. During 2009 average air temperature was $19.45^{\circ} \mathrm{C}$, which was $1.4^{\circ} \mathrm{C}$ higher than the average temperature in 2010.

High air temperatures and precipitation deficit during April and May of 2009 caused delays in soybean growth. End of May and early July were followed by precipitation which had a favourable effect on soybean growth and development. There was an arid period from mid-July to September. Soybean had lower aboveground mass and relatively stronger root system. As soybean plant is very sensitive to the lack of soil moisture during flowering and grain filling, it reflected on the yield. In contrast to 2009 , monthly precipitation distribution during the humid 2010 was more favourable and it reflected on soybean plants growth and contributed to the achievement of higher yields.

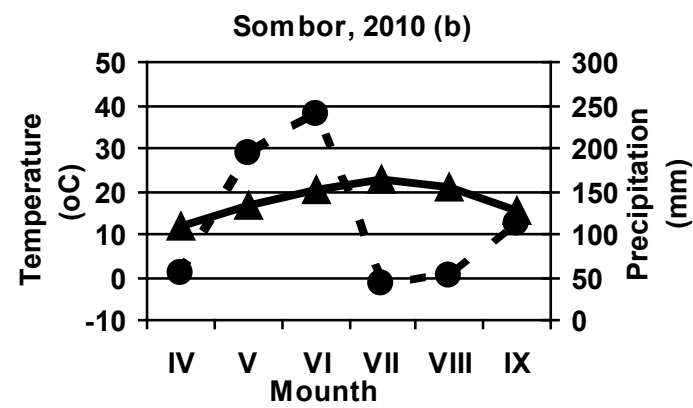

Figure $1 \mathrm{a}, \mathrm{b}$. Mean daily temperature $\left({ }^{\circ} \mathrm{C}\right)$ and total precipitation $(\mathrm{mm})$ during the growing season in soybean growing period in Sombor, Serbia (2009-2010) 


\section{Results and Discussion}

\section{Soybean grain yield}

Year, variety and their mutual interactions had a statistically significant effect ( $<<0.05, p<0.01)$ on soybean grain yield. All the tested varieties achieved high, relatively yield. Yields ranged from $3.918 \mathrm{~kg}$ $\mathrm{ha}^{-1}$ (Proteinka) to $4,450 \mathrm{~kg} \mathrm{ha}^{-1}$ (Balkan). There was statistical significance among the achieved yields for the tested varieties. The average yield for all soybean tested varieties in the two-year period was $4,196 \mathrm{~kg} \mathrm{ha}^{-1}$ (Table 1 and 2). Since the studied years were agro-meteorologically divergent, 2009 relatively arid and 2010 humid, large fluctuations in the yields and stability were recorded.

Bečejka $\left(5,963 \mathrm{~kg} \mathrm{ha}^{-1}\right)$ and Balkan $(5,960 \mathrm{~kg}$ $\mathrm{ha}^{-1}$ ) yielded statistically significantly higher in 2010 compared to the other tested varieties, except for Galina $\left(5,573 \mathrm{~kg} \mathrm{ha}^{-1}\right)$. The lowest average yield in 2010 was achieved by Proteinka $\left(4,960 \mathrm{~kg} \mathrm{ha}^{-1}\right)$. The higher yield in 2009 was achieved by Sava variety $\left(3,132 \mathrm{~kg} \mathrm{ha}^{-1}\right)$, as shown in Tables 1 and 2 .
In 2010 yields were significantly higher $(5,503$ $\left.\mathrm{kg} \mathrm{ha}^{-1}\right)$ compared to the yields in $2009(2,889 \mathrm{~kg}$ $\left.\mathrm{ha}^{-1}\right)$, Tab. 1. Irrigation is the only measure that can fully solve the problems of drought in the years such as 2009.

Pejić et al. (2012) reported that soybean yields are projected to significantly increase under irrigation. Hrustić et al. (2002) and Miladinović et al. (2008) reported that there was the greatest negative influence on yield and grain quality due to lack of water during the time of formation and grain filling (R5-R6). These stages take place in August, when lack of precipitation is common in our environmental conditions.

The average Standard Error for yield for all soybean tested varieties in the two-year period was 238.31 (Table 2).

Within the year, tested varieties recorded yield stability, $\mathrm{Cv}=7.71 \%$ (2009) and $\mathrm{Cv}=7.95 \%$ (2010), Tab. 1. By monitoring variety $\mathrm{x}$ year interaction, it is obvious that yield was statistically significantly higher in 2010 for all investigated varieties $(\mathrm{p}<0.01)$, Tab. 1.1.

Table 1. Soybean yield $\left(\mathrm{kg} \mathrm{ha}^{-1}\right)$ in Sombor, Serbia, 2009-2010

\begin{tabular}{|c|c|c|c|c|c|}
\hline \multirow{2}{*}{ Variety } & \multirow{2}{*}{ MG } & \multicolumn{4}{|c|}{ Grain yield, kg ha ${ }^{-1}$} \\
\hline & & 2009 & 2010 & $2009-2010$ & $\mathrm{C}_{\mathrm{V}}$ \\
\hline Galina & 0 & 2,464 & 5,573 & 4,019 & 54.71 \\
\hline Valjevka & 0 & 2,831 & 5,087 & 3,959 & 40.28 \\
\hline Bečejka & 0 & 2,795 & 5,963 & 4,379 & 51.16 \\
\hline Proteinka & 0 & 2,876 & 4,960 & 3,918 & 37.61 \\
\hline \multicolumn{2}{|c|}{ Average $0 \mathrm{MG}$} & 2,742 & 5,396 & 4,056 & 46.12 \\
\hline Balkan & $\mathrm{I}$ & 2,939 & 5,960 & 4,450 & 48.01 \\
\hline Sava & $\mathrm{I}$ & 3,132 & 5,260 & 4,196 & 35.68 \\
\hline \multicolumn{2}{|c|}{ Average I MG } & 3,036 & 5,610 & 4,323 & 42.11 \\
\hline \multicolumn{2}{|c|}{ Average 2009} & 2,889 & - & - & 7.71 \\
\hline \multicolumn{2}{|c|}{ Average 2010} & - & 5,503 & - & 7.95 \\
\hline \multicolumn{2}{|c|}{ Average, 2009-2010 } & - & - & 4,196 & 44.73 \\
\hline
\end{tabular}

\begin{tabular}{|c|c|c|c|}
\hline LSD test & Variety & Year & V x Y \\
\hline 0.05 & 589 & 340 & 834 \\
0.01 & 799 & 461 & 1129 \\
\hline
\end{tabular}

Table 1.1. Analysis of variance for yield

\begin{tabular}{|c|c|c|c|c|c|}
\hline Effect & SS & Deg. of Freedom & MS & F & P \\
\hline Intercept & 621039627 & 1 & 621039627 & 2540,412 & 0,000000 \\
\hline Variety & 1511505 & 5 & 302301 & 1,237 & 0,323038 \\
\hline Year & 62136434 & 1 & 62136434 & 254,174 & 0,000000 \\
\hline Variety x Year & 2044638 & 5 & 408928 & 1,673 & 0,179534 \\
\hline Error & 5867140 & 24 & 244464 & & \\
\hline
\end{tabular}


Table 2. Descriptive statistics for yield

\begin{tabular}{|l|c|c|c|c|c|c|c|}
\hline \multicolumn{1}{|c|}{ Effect } & Level of factor & $\mathrm{N}$ & Yield Mean & Yield Std. Dev. & Yield Std. Err & $\begin{array}{c}\text { Yield } \\
-95.00 \%\end{array}$ & $\begin{array}{c}\text { Yield } \\
+95.00 \%\end{array}$ \\
\hline Total & & 36 & 4,196 & $1,429.88$ & 238.31 & $3,669.64$ & $4,637.25$ \\
\hline Variety & Valjevka & 6 & 3,959 & $1,313.40$ & 536.19 & $2,580.50$ & $5,337.17$ \\
\hline Variety & Galina & 6 & 4,019 & $1,785.18$ & 728.79 & $2,145.23$ & $5,892.10$ \\
\hline Variety & Proteinka & 6 & 3,918 & $1,195.04$ & 487.87 & $2,664.05$ & $5,172.28$ \\
\hline Variety & Sava & 6 & 4,196 & $1,350.16$ & 551.19 & $2,779.62$ & $5,613.07$ \\
\hline Variety & Bečejka & 6 & 4,379 & $1,755.41$ & 716.64 & $2,536.98$ & $6,220.35$ \\
\hline Variety & Balkan & 6 & 4,450 & $1,662.89$ & 678.88 & $2,704.56$ & $6,194.77$ \\
\hline \multicolumn{7}{|l|}{} \\
\hline Year & 2009 & 18 & 2,889 & 387.89 & 91.43 & $2,646.77$ & $3,032.56$ \\
\hline Year & 2010 & 18 & 5,503 & 635.48 & 149.78 & $5,151.20$ & $5,783.24$ \\
\hline
\end{tabular}

Table 3. Protein content (\%) of soybean in Sombor, Serbia, 2009-2010

\begin{tabular}{|c|c|c|c|c|c|}
\hline \multirow{2}{*}{ Variety } & \multirow{2}{*}{ MG } & \multicolumn{5}{|c|}{ Protein content, \% } \\
\cline { 3 - 6 } & & 2009 & 2010 & $2009-2010$ & $\mathrm{C}_{\mathrm{V}}$ \\
\hline Galina & 0 & 37.10 & 36.22 & 36.66 & 1.69 \\
\hline Valjevka & 0 & 36.72 & 36.44 & 36.58 & 0.54 \\
\hline Bečejka & 0 & 36.16 & 38.38 & 37.27 & 4.21 \\
\hline Proteinka & 0 & 37.32 & 38.33 & 37.82 & 1.91 \\
\hline Average 0 MG & & 36.82 & 37.34 & 37.08 & 0.99 \\
\hline Balkan & I & 36.86 & 37.31 & 37.08 & 0.85 \\
\hline Sava & I & 36.04 & 37.52 & 36.78 & 2.85 \\
\hline Average I MG & & 36.45 & 37.42 & 36.94 & 1.83 \\
\hline Average 2009 & & 36.64 & - & - & 1.39 \\
\hline Average 2010 & - & 37.38 & - & 2.44 \\
\hline Average, 2009-2010 & - & - & 37.01 & 1.28 \\
\hline
\end{tabular}

\begin{tabular}{|c|c|c|c|}
\hline LSD test & Variety & Year & V x Y \\
\hline 0.05 & 1.16 & 0.67 & 1.64 \\
0.01 & 1.57 & 0.91 & 2.22 \\
\hline
\end{tabular}

Table 3.1. Analysis of variance of protein content

\begin{tabular}{|c|c|c|c|c|c|}
\hline Effect & SS & Deg. of Freedom & MS & F & P \\
\hline Intercept & 49371,36 & 1 & 49371,36 & 52370,13 & 0,000000 \\
\hline Variety & 6,54 & 5 & 1,31 & 1,39 & 0,263968 \\
\hline Year & 4,01 & 1 & 4,01 & 4,26 & 0,050064 \\
\hline Variety x Year & 9,77 & 5 & 1,95 & 2,07 & 0,104126 \\
\hline Error & 22,63 & 24 & 0,94 & & \\
\hline
\end{tabular}


Average yield of the 0 maturity group varieties $\left(4,056 \mathrm{~kg} \mathrm{ha}^{-1}\right)$ was lower compared to the maturity group I varieties $\left(4,323 \mathrm{~kg} \mathrm{ha}^{-1}\right)$ by $267 \mathrm{~kg} \mathrm{ha}^{-1}$, i.e. by $6.58 \%$ (Tab. 1,2$)$.

Table. 4. Descriptive statistics for protein content

\begin{tabular}{|l|l|c|c|c|c|c|c|}
\hline \multicolumn{1}{|c|}{ Effect } & Level of factor & $\mathrm{N}$ & $\begin{array}{c}\text { Protein } \\
\text { Mean }\end{array}$ & $\begin{array}{c}\text { Protein } \\
\text { Std. Dev. }\end{array}$ & $\begin{array}{c}\text { Protein Std. } \\
\text { Err }\end{array}$ & $\begin{array}{c}\text { Protein } \\
-95.00 \%\end{array}$ & $\begin{array}{c}\text { Protein } \\
+95.00 \%\end{array}$ \\
\hline Total & & 36 & 37.01 & 1.11 & 0.18 & 36.66 & 37.41 \\
\hline Variety & Valjevka & 6 & 36.58 & 1.39 & 0.57 & 35.11 & 38.05 \\
\hline Variety & Galina & 6 & 36.66 & 1.19 & 0.48 & 35.42 & 37.90 \\
\hline Variety & Proteinka & 6 & 37.82 & 0.88 & 0.36 & 36.89 & 38.75 \\
\hline Variety & Sava & 6 & 36.78 & 0.98 & 0.40 & 35.45 & 37.81 \\
\hline Variety & Bečejka & 6 & 37.27 & 1.36 & 0.56 & 35.85 & 38.70 \\
\hline Variety & Balkan & 6 & 37.08 & 0.57 & 0.23 & 36.48 & 37.68 \\
\hline & \multicolumn{7}{|l|}{} \\
\hline Year & 2009 & 18 & 36.64 & 1.11 & 0.26 & 36.15 & 37.25 \\
\hline Year & 2010 & 18 & 37.38 & 1.03 & 0.24 & 36.85 & 37.88 \\
\hline
\end{tabular}

Table 5. Oil content (\%) of soybean in Sombor, Serbia, 2009-2010

\begin{tabular}{|c|c|c|c|c|c|}
\hline \multirow{2}{*}{ Variety } & \multirow{2}{*}{ MG } & \multicolumn{4}{|c|}{ Oil content, \% } \\
\hline & & 2009 & 2010 & 2009-2010 & $\mathrm{C}_{\mathrm{V}}$ \\
\hline Galina & 0 & 21.89 & 19.88 & 20.88 & 6.81 \\
\hline Valjevka & 0 & 21.27 & 20.32 & 20.79 & 3.23 \\
\hline Bečejka & 0 & 22.17 & 19.31 & 20.74 & 9.75 \\
\hline Proteinka & 0 & 22.39 & 19.55 & 20.97 & 9.58 \\
\hline \multicolumn{2}{|c|}{ Average $0 \mathrm{MG}$} & 21.93 & 19.76 & 20.85 & 7.36 \\
\hline Balkan & I & 21.73 & 19.57 & 20.65 & 7.40 \\
\hline Sava & $\mathrm{I}$ & 23.03 & 20.04 & 21.53 & 9.81 \\
\hline \multicolumn{2}{|c|}{ Average I MG } & 22.38 & 19.81 & 21.09 & 8.65 \\
\hline \multicolumn{2}{|c|}{ Average 2009} & 22.16 & - & - & 2.73 \\
\hline \multicolumn{2}{|c|}{ Average 2010} & - & 19.78 & - & 1.84 \\
\hline \multicolumn{2}{|c|}{ Average, 2009-2010 } & - & - & 20.93 & 9.47 \\
\hline \multicolumn{2}{|c|}{ LSD test } & Variety & \multicolumn{2}{|c|}{ Year } & \\
\hline \multicolumn{2}{|c|}{$\begin{array}{l}0.05 \\
0.01\end{array}$} & $\begin{array}{l}0.70 \\
0.95\end{array}$ & \multicolumn{2}{|c|}{$\begin{array}{l}0.41 \\
0.55\end{array}$} & \\
\hline
\end{tabular}

Table 5.1. Analysis of variance of oil content

\begin{tabular}{|c|c|c|c|c|c|}
\hline Effect & SS & Deg. of Freedom & MS & F & P \\
\hline Intercept & 15768,24 & 1 & 15768,24 & 45377,33 & 0,000000 \\
\hline Variety & 3,01 & 5 & 0,60 & 1,73 & 0,165833 \\
\hline Year & 47,77 & 1 & 47,77 & 137,47 & 0,000000 \\
\hline Variety x Year & 4,53 & 5 & 0,91 & 2,61 & 0,050922 \\
\hline Error & 8,34 & 24 & 0,35 & & \\
\hline
\end{tabular}


recorded significantly higher protein content compared to other analysed varieties, $\mathrm{p}<0.05$ (Tab. 3, 4).

The average Standard Error for protein content for all soybean tested varieties in the two-year period was 0.18 (Table 4).

Year 2010 was favourable for protein synthesis. Stable protein content was recorded within years for tested varieties, $\mathrm{C}_{\mathrm{v}}=1.39 \%$ (2009) and $\mathrm{Cv}$ $=2.44 \%$ (2010), Table 3. Based on the LSD-test variety and interaction genotype $\mathrm{x}$ year $(\mathrm{G} \times \mathrm{Y})$ had a statistically significant effect $(\mathrm{p}<0.05)$ on protein content in soybean grain. Analysed years were not statistically significant $(\mathrm{p}>0.05)$, Table 3.1.

Monitoring of variety $x$ year interaction shows that the average protein content was higher in 2010. Significantly higher protein content, compared among all tested varieties, was achieved by Bečejka (38.38\%) in 2010 with the exception of Proteinka $(38.33 \%)$ which had relatively uniformed protein content. The higher protein content in 2009 was found in Proteinka (37.32\%), (Table 3, 4).

The average protein content of maturity group 0 varieties (37.08\%) was higher than the maturity group I varieties (36.94\%), Table 3.

\section{Oil content}

The average oil content was $20.93 \%$ for all analysed genotypes in the period 2009-2010. Year had a statistically significant effect $(\mathrm{p}<0.01)$, on the oil content in soybean grain (Table $5,5.1$ ).

During the analysed period Sava variety $(21.53 \%)$ recorded significantly higher average oil content compared to Balkan, Bečejka and Valjevka varieties, $\mathrm{p}<0.05$. Among other varieties, on average there was no significant difference in oil content (Tab. 5, 6). All tested varieties recorded stability in oil content within investigated year, $\mathrm{Cv}=2.73 \%$ (2009) and $\mathrm{Cv}=1.84 \%$ (2010).

The realized average oil content for all varieties in 2009 (22.16\%) was statistically significantly higher than in 2010 (19.78\%). The higher oil content in 2009 was achieved by Sava variety (23.03\%), and the higher oil content in 2010 was achieved by Valjevka variety (20.32\%), Table 5.

The average Standard Error for oil content for all soybean tested varieties in the two-year period was 0.22 (Table 6).

The average oil content in 2009-2010 of 0 maturity group varieties (20.85\%) was lower compared to the maturity group I varieties (21.09\%), Tables 5, 6.

Year and variety $\mathrm{x}$ year interaction had a statistically significant effect $(\mathrm{p}<0.05)$, Tab. 5 , on the oil content in soybean grain.

Our results are in accordance with the results of Popović et al. (2012), where the authors stated that there are always several factors which both independently and in interactions cause the success of certain soybean variety application in soybean production, and therefore the success of the production. Besides genetic factors, agroecological factors had a major impact on the variability of analysed variety traits. Highly significant interaction year $\mathrm{x}$ variety showed that there were differences in the expression of analysed traits in soybean.

The same authors report that average yield for the same variety amounted to $3,657 \mathrm{~kg} \mathrm{ha}^{-1}, 38.04 \%$ protein content and oil content of $20.54 \%$ at Rimski Šančevi locality during 2009-2010. Based on the previous, it can be concluded that besides genetic and agro-ecological factors, variability of examined soybean traits, as well as growing locality, affected soybean production the most.

Table 6. Descriptive statistics for oil content

\begin{tabular}{|l|l|c|c|c|c|c|c|}
\hline \multicolumn{1}{|c|}{ Effect } & Level of factor & $\mathrm{N}$ & $\begin{array}{c}\text { Oil } \\
\text { Mean }\end{array}$ & $\begin{array}{c}\text { Oil } \\
\text { Std. Dev. }\end{array}$ & $\begin{array}{c}\text { Oil } \\
\text { Std. Err }\end{array}$ & $\begin{array}{c}\text { Oil } \\
-95.00 \%\end{array}$ & $\begin{array}{c}\text { Oil } \\
+95.00 \%\end{array}$ \\
\hline Total & & 36 & 20.93 & 1.35 & 0.22 & 20.47 & 21.38 \\
\hline Variety & Valjevka & 6 & 20.79 & 0.80 & 0.33 & 19.95 & 21.64 \\
\hline Variety & Galina & 6 & 20.88 & 1.22 & 0.50 & 19.59 & 22.17 \\
\hline Variety & Proteinka & 6 & 20.97 & 1.61 & 0.66 & 19.28 & 22.66 \\
\hline Variety & Sava & 6 & 21.53 & 1.67 & 0.68 & 19.78 & 23.28 \\
\hline Variety & Bečejka & 6 & 20.74 & 1.73 & 0.71 & 18.92 & 22.55 \\
\hline Variety & Balkan & 6 & 20.65 & 1.27 & 0.52 & 19.32 & 21.98 \\
\hline & & 18 & 22.16 & 0.83 & 0.19 & 21.66 & 22.49 \\
\hline Year & 2009 & 18 & 19.78 & 0.50 & 0.12 & 19.53 & 20.03 \\
\hline Year & 2010 & & & & & \\
\hline
\end{tabular}


Table 7. Correlations between yield, protein and oil content in soybean grain (2009-2010)

(Correlation parameters for 2009 above diagonal and for 2010 below diagonal)

\begin{tabular}{|c|c|c|c|}
\hline Parameter & Yield & Protein content & Oil content \\
\hline Yield & 1.00 & $-0.02^{\mathrm{ns}}$ & $0.10^{\mathrm{ns}}$ \\
\hline Protein content & $-0.42^{\mathrm{ns}}$ & 1.00 & $-0.41^{\mathrm{ns}}$ \\
\hline Oil content & $0.35^{\mathrm{ns}}$ & $-0.70^{* *}$ & 1.00 \\
\hline
\end{tabular}

${ }^{\mathrm{ns}}$ - not significant; ${ }^{* *}$ - significant at $\mathrm{p}<0.01$

\section{The interdependence of the traits}

The oil content in soybean grain was statistically highly significantly negatively correlated with protein content $\left(\mathrm{r}=-0.70^{* *}\right)$ in 2010 and less significantly negatively correlated in 2009 ( $\mathrm{r}=$ $-0.41)$, Table 7.

The interaction of the analysed factors, year $\mathrm{x}$ variety, exerts a statistically significant effect on the correlations among protein and oil content.

The results of negative correlation of protein and oil content in soybean grain were in accordance with the results of numerous authors (Kravchenko \& Bullock 2002, Popovic et al. 2012, 2013).

\section{Conclusions}

Based on annual research and variety influence on productivity and quality of soybean grain, the following conclusions can be drawn:

Significant differences in yield, protein and oil contents were determined in dependence of the variety and the year $(p<0.05)$. Interaction of factors also reveals a statistically significant effect on soybean yield, protein and oil content $(\mathrm{p}<0.05)$.

Average yields were statistically highly significantly higher in 2010 compared to 2009. Favourable year for oil synthesis in soybean grain for all varieties was 2009 and protein synthesis 2010, with the exception of Galina (2009).

Proteinka achieved the highest average protein contents compared to other tested varieties, while the highest average oil content were observed in Proteinka, Sava and Galina.

Oil content in soybean grain was in statistically highly significant negative correlation with protein content $\left(\mathrm{r}=-0.70^{* *}\right)$.

Large fluctuations in yield, protein and oil contents show that, besides genetic factors, analysed traits largely depend on the amount and distribution of precipitation and temperature conditions. 


\section{References}

Cahoon, E.B. (2003). Genetic enhancement of soybean oil for industrial uses: Prospects and challenge, Ag. Bio Forum, 6, 1113

Hurburgh, C.R. (2000). Quality of the 2000 soybean crop from the USA. American Soybean Association Azia Quality Seminar, December 5, 2000.

Hrustić, M., Vidić, M., \& Miladinović, J. (2002). Stability of yield and oil and protein content in

new and cultivated soybean genotypes. Proceedings of the Institute of Field and Vegetable Crops. 36, 115-124.

Jayakumar, K., Azooz, M.M., Vijayarengan, P., \& Abdul Jaleel, C. (2010). Biochemical changes with exogenous cobalt application in soybean, J. Phytology, 2, 7-12.

Kravchenko, A.N., \& Bullock, D.G. (2002). Spatial variability of soybean quality data as a function of field topography II: A proposed technique for calculating the size of the area for differential soybean harvest. Crop Sci. 42, 816-821.

McCord, K.L., Fehr, W.R., Wang, T., Welke, G.A., Cianzio, S.R., \& Schnebly, S.R. (2004). Tocopherol content of soybean lines with reduced linolenate in the seed oil, Crop Sci. 44, 772-776.

Miladinović, J., Hrustić, M., \& Vidić, M. (2008). Soybean. Institut za ratarstvo i povrtarstvo, Novi Sad, Sojaprotein, Bečej.

Pejić, B., Bošnjak, Đ., Mačkić, K., Rajić, M., Josipović, M., Jug, I., \& Maksimović, L. (2012). Yield and Water Use Efficiency of Irrigated Soybean in Vojvodina, Serbia. Ratar. Povrt., 49(1), 80-85.

Popović, M.V. (2010). Agrotehnički i agroekološki uticaji na proizvodnju semena pšenice, kukuruza i soje. $\mathrm{PhD}$ Thesis, Univerzitet u Beogradu, Poljoprivredni fakultet Zemun, 21-32.

Popović, V., Vidić, M., Tatić, M., \& Kostić, M. (2012). The effect of cultivar and year on yield and quality components in soybean. Ratar. Povrt., 49(1), 132-139.

Popović, V., Malešević, M., Miladinović, J., Marić, V., \& Živanović, $\mathrm{Lj}$. (2013). Effect of agroecolo-gical factors on variations in yield, protein and oil contents in soybean grain. Romanian Agricultural Research, 30(24), 241-248.

Vidić, M., Miladinović, J., Popović, V., Đukić, V., \& Đorđević, V. (2010). Rubin, Idila and Trijumf - New late NS soybean cultivars, Selekcija i semenarstvo, 16(1), 47-53.

\title{
Produktivne i kvalitativne osobine zrna soje u agroekološkim uslovima Sombora
}

\author{
Vera Popović • Jegor Miladinović • Miloš Vidić • Mladen Tatić • \\ Vladimir Sikora • Jela Ikanović • Gordana Dozet
}

Sažetak: U dvogodišnjim istraživanjima prikazani su rezultati prinosa zrna, sadržaja proteina i ulja u NS sortama soje. Podaci su obrađeni analizom varijanse po metodi dvofaktorijalnog ogleda (sorta, godina). Značajnost razlika testirana je LSD testom. Statistički značajno viši prinosi zabeleženi su 2010. u odnosu na 2009. godinu. Prosečni prinosi, za testirane sorte soje, iznosili su $4.154 \mathrm{~kg} \mathrm{ha}^{-1} \mathrm{i}$ varirali su od $2.840 \mathrm{~kg} \mathrm{ha}^{-1}(2009)$ do $5.467 \mathrm{~kg} \mathrm{ha}^{-1}$ (2010). Povoljnija godina za sintezu proteina bila je 2010. Najviši sadržaj proteina u 2010. ostvarile su u proseku sorte Bečejka (38,38\%) i Proteinka (38,33\%). Sadržaj proteina za sve ispitivane sorte soje iznosio je u proseku 37,03\%. Sorta Proteinka imala je, u dvogodišnjem proseku, statistički značajno viši prosečan sadržaj proteina u odnosu na ostale testirane sorte. Prosečan sadržaj ulja, za sve testirane sorte soje, iznosio je 20,93\%. Najviši sadržaj ulja u 2009. godini ostvarila je u sorta Sava (23,03\%). Statistički značajno viši sadržaj ulja zabeležen je u 2009. u odnosu na 2010. Godina, sorta i njihove interakcije imale su statistički značajan uticaj $(\mathrm{p}<0,05, \mathrm{p}<0,01)$ na prinos i kvalitet zrna soje. $U$ aridnim godinama navodnjavanje i pravilna agrotehnika su jedine mere kojima se mogu ublažiti limitirajući faktori i povećati prinosi.

Ključne reči: prinos zrna, sadržaj proteina, sadržaj ulja, soja, sorta 